УДК 615.322:615.25+615.071:582.736

DOI https://doi.org/10.11603/2312-0967.2019.1.9883

\title{
МОРФОЛОГО-АНАТОМІЧНЕ ДОСЛІДЖЕННЯ ТРАВИ АСТРАГАЛУ СОЛОДКОЛИСТОГО (ASTRAGALUS GLYCYPHYLLOS L.)
}

\author{
Р. М. Лисюк ${ }^{1}$, Н. П. Ковальська ${ }^{2}$ \\ Львівський національний медичний університет імені Данила Галицького ${ }^{1}$ \\ Національний медичний університет імені О. О. Богомольця², Київ \\ pharmacognosy.org.ua@ukr.net
}

\begin{abstract}
Мета роботи. Встановлення морфолого-анатомічних діагностичних ознак трави астрагалу солодколистого. Матеріали і методи. Мікропрепарати виготовляли з фрагментів трави астрагалу солодколистого, фріксованих у розчині хлоралгідрату, і досліджували загальноприйнятими методами з використанням тринокулярного світлового мікроскопа ULAB при збільшенні в 40, 100 та 400 разів; фротофріксацію результатів здійснювали за допомогою дзеркальної фотокамери Canon EOS 550.

Результати й обговорення. Діагностичними мікроскопічними ознаками сировини можна вважати трихоми, які складаються з 1-2 коротких базальних клітин та однієї великої видовженої термінальної клітини з бородавчастою кутикулою; термінальна клітина прикріплюється до ніжки з базальних клітин одним зі своїх країв, який заокруглений, інший її край загострений. Проведено дослідження фррагментів висушених та свіжозібраних листків, стебел, рахісу та квіток; у результаті проведення аналізу поперечних зрізів із свіжої трави астрагалу солодколистого встановлено особливості локалізації слизу, пектинів та френольних сполук в аналізованій рослинній сировині.

Висновки. Встановлено морфологічні та анатомічні діагностичні ознаки надземної частини астрагалу солодколистого, перспективного нефропротекторного засобу. Отримані дані буде використано при розробці проекту методів контролю якості на нову лікарську рослинну сировину - «Трава астрагалу солодколистого».
\end{abstract}

Ключові слова: астрагал солодколистий; трава; нефропротектор; морфологічні, анатомічні ознаки.

Вступ. Обмежений асортимент лікарських засобів рослинного походження вітчизняного виробництва 3 доведеною гіпоазотемічною активністю спонукає до пошуку нових нефропротекторних (гіпоазотемічних) препаратів, розроблених на основі видів вітчизняної фрлори з достатньою ресурсною базою [1].

Астрагал солодколистий (Astragalus glycyphyllos L.) AC) - лікарська рослина, яку здавна використовують у народній медицині. Значний вміст робініну та інших фрлавоноїдів, а також ресурсний потенціал виду становить інтерес дня науковців [2-5]. У деяких регіонах Європи AC застосовують як замінник чаю [6]. A. glycyphyllos - кормова й силосна культура, має декоративне значення та придатний для зміцнення ґрунту [7].

Астрагал солодколистий - багаторічна трав'яниста гола або негусто білувато-опушена рослина родини Бобових (Fabaceae). Стебло висхідне, розгалужене, 45-90 см заввишки. Листки чергові, непарноперисті, 3 4-7 пар видовжено-еліптичних, зісподу волосистих листочків. Квітки зеленувато-жовті, у коротких густих китицях. Плід - біб, лінійний, зігнутий дугою. Цвіте у червні - серпні [8, 9]. Зростає A. glycyphyllos по всій території України у мішаних лісах, на узліссях, полях, по чагарниках $[7,9]$.

Трава AC містить орлавоноїди, тритерпенові сапоніни (гліциризин), гідроксикоричні кислоти, стероли, сахариди, амінокислоти, гіркі й дубильні речовини, органічні кислоти, манітол, сліди алкалоїдів, аскорбінову кислоту [2, 3, 6, 7, 9-11]. Серед 9 ідентифікованих моносахаридів найбільший вміст було встановлено для (+)-пінітолу, D-глюкози та сахарози [12]. Флавоноїдні компоненти трави A. glycyphyllos представлені апігеніном, кемферолом та їхніми глікозидами, кверцитрином, ізорамнетином [4, 13].

Рослину за її дією відносять до жовчогінних, сечогінних, відхаркувальних, заспокійливих, судинорозширювальних засобів [2, 8, 10, 14]. У народній вітчизняній і зарубіжній медицині АС рекомендують при захворюваннях нирок та сечових шляхів, при каменях нирок $[7,9,14]$. Настої трави астрагалу також застосовують при гіпертонічній хворобі, хронічній серцево-судинній недостатності та інших захворюваннях нирок $[8,14]$.

На даний час $A$. glycyphyllos розглядають як фрармакологічний аналог астрагалу шерстистоквіткового і вважають перспективним джерелом вітамінно-мінерального комплексу та антиоксидантних біологічно активних сполук $[2,3,5,14]$.

Дані щодо макро- і мікроскопічних ознак офріцинальних видів роду Астрагал наведено в публікаціях вітчизняних вчених $[15,16]$.

Оскільки вивчення діагностичних ознак як важливих критеріїв стандартизації для перспективних рослинних

ISSN 2312-0967. Pharmaceutical review. 2019. № 1 
субстанцій є одним з важливих етапів фрармацевтичного аналізу, зокрема при опрацюванні специсрікації на сировину [17], метою даного дослідження став аналіз морфолого-анатомічної структури надземних органів AC та встановлення їх основних діагностичних ознак.

Матеріали і методи. Дослідження мікроскопічної будови трави АС проводили методом світлової мікроскопії. Використовували траву висушену, заготовлену в м. Львів, та свіжу - зібрану в околицях м. Отинія, Івано-Франківської обл. у червні 2017 р. Досліджувані сировинні органи ідентифіковано авторами за морфологічними ознаками $[18,19]$.

Висушену сировину для виготовлення мікропрепаратів розм'якшували кип'ятінням у 5 \% розчині натрію гідроксиду. 3 розм'якшених об'єктів відразу виготовляли тимчасові препарати.

Із свіжої трави AC за допомогою леза виготовляли поперечні зрізи через листкову пластинку, рахіс, стебло і поверхневі препарати верхньої і нижньої епідерми, заключали тимчасові мікропрепарати у воду очищену. Аналогічно виготовляли мікропрепарати зі свіжої сировини і з додаванням спиртового розчину метиленового синього (1:5000).

Мікропрепарати переглядали під мікроскопом, застосовуючи розчин хлоралгідрату. Для вивчення тимчасових препаратів використовували тринокулярний світловий мікроскоп фрірми ULAB при збільшенні в 40, 100 та 400 разів. Фотографували зрізи за допомогою дзеркальної фротокамери Canon EOS 550.

Результати й обговорення. У результаті проведеного аналізу встановлено такі макроскопічні ознаки досліджуваної сировини - трави АС (рис. 1): стебло зелене, опушене білуватими волосками або майже голе, борозенчасте. Листки чергові, черешкові, непарноперисті, із ланцетоподібними, загостреними, вільними, жовто-зеленими прозорими прилистками, 1520 мм завдовжки; листочки видовжено-яйцеподібні або еліптичні, на верхівці притуплені, зрідка притиснуті, 1,8-6 см завдовжки; верхня поверхня зелена, гола, нижня - білувата, опушена. Суцвіття - видовжена гус- та китиця із численних зеленувато-жовтих квіток, 1115 мм завдовжки; квітка має дзвоникувату чашечку 3 нерівними шилоподібними зубцями, голу або інколи опушену та метеликоподібний віночок. Плід - нерозкривний біб, 3-4 см завдовжки, 4-5 мм завширшки, дещо серпоподібнозігнутий, зближений $з$ іншими бобами, які сходяться між собою верхівками; поверхня плоду гола, інколи з поодинокими волосками.

3 метою встановлення основних мікроскопічних діагностичних ознак трави АС, проведено аналіз фррагментів висушених і свіжозібраних листків, стебел, рахісу та квітів. Для виявлення локалізації слизу, пектинів і фенольних сполук у листковій пластині, рахісі й стеблі було проведено мікроскопічне дослідження з використанням спиртового розчину метиленового синього та розчину феруму (III) хлориду на поперечних зрізах із свіжої трави АС.

Листки. Листкова пластинка дуже тонка, дорзивентральна, амфістоматична. Верхня епідерма (рис. 2) характеризується тонкостінними багатокутними клітинами із слабозвивистими стінками, які по-

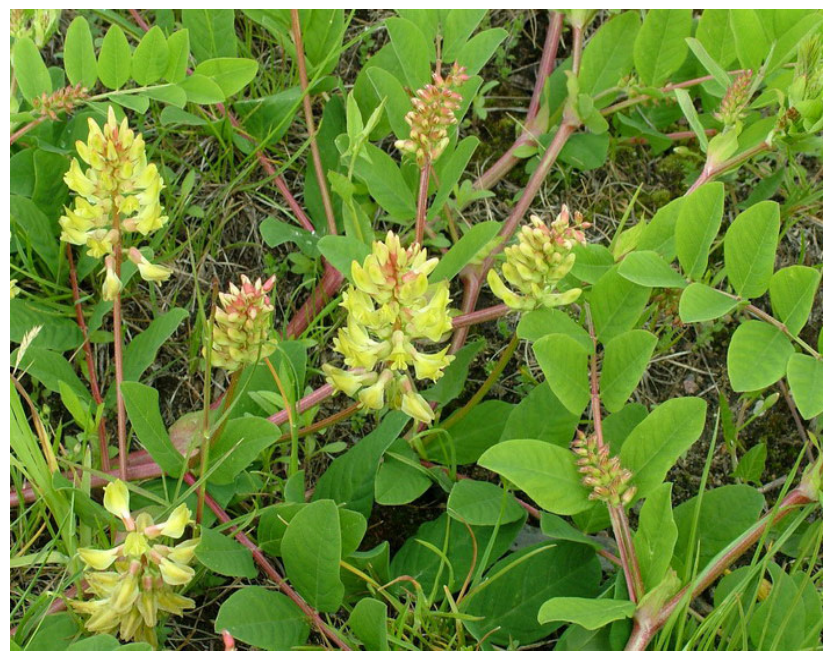

Рис. 1. Зовнішній вигляд надземних органів астрагалу солодколистого.

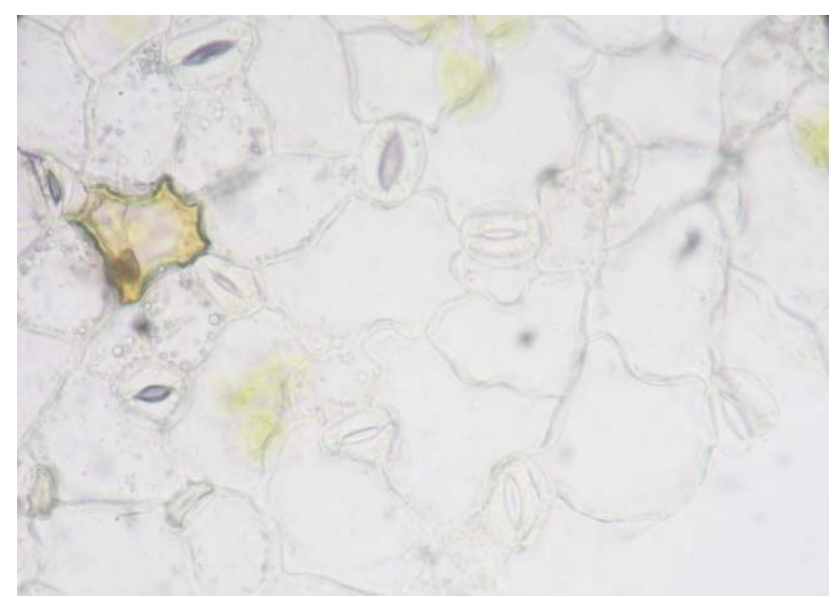

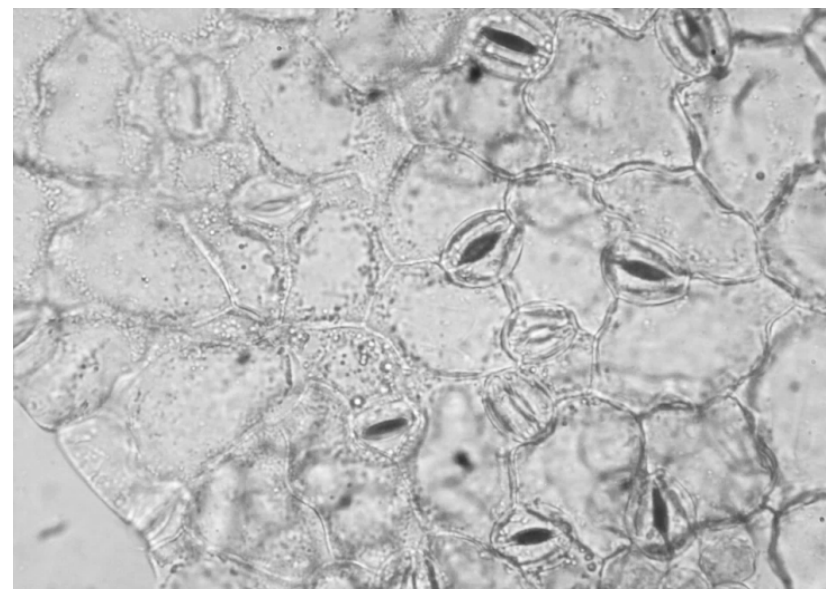

Рис. 2. Верхня епідерма астрагалу солодколистого (зб.1:400).

ISSN 2312-0967. Фармацевтичний часопис. 2019. № 1 
криті зморшкуватою кутикулою. Клітини нижньої епідерми більш звивистостінні, ніж клітини верхньої епідерми. Епідермальні клітини над жилкою і по краю листочків прямостінні, видовжені. Продихи округлі. Продиховий комплекс аномоцитного типу.
На нижній епідермі листка АС (рис. 3) розташовані трихоми, які рівномірно розподілені по всій листковій пластинці, а вздовж жилок і по краю листкової пластинки зустрічаються частіше. Прості волоски притиснуті до поверхні листка (рис. 4). Складаються 3 1-2
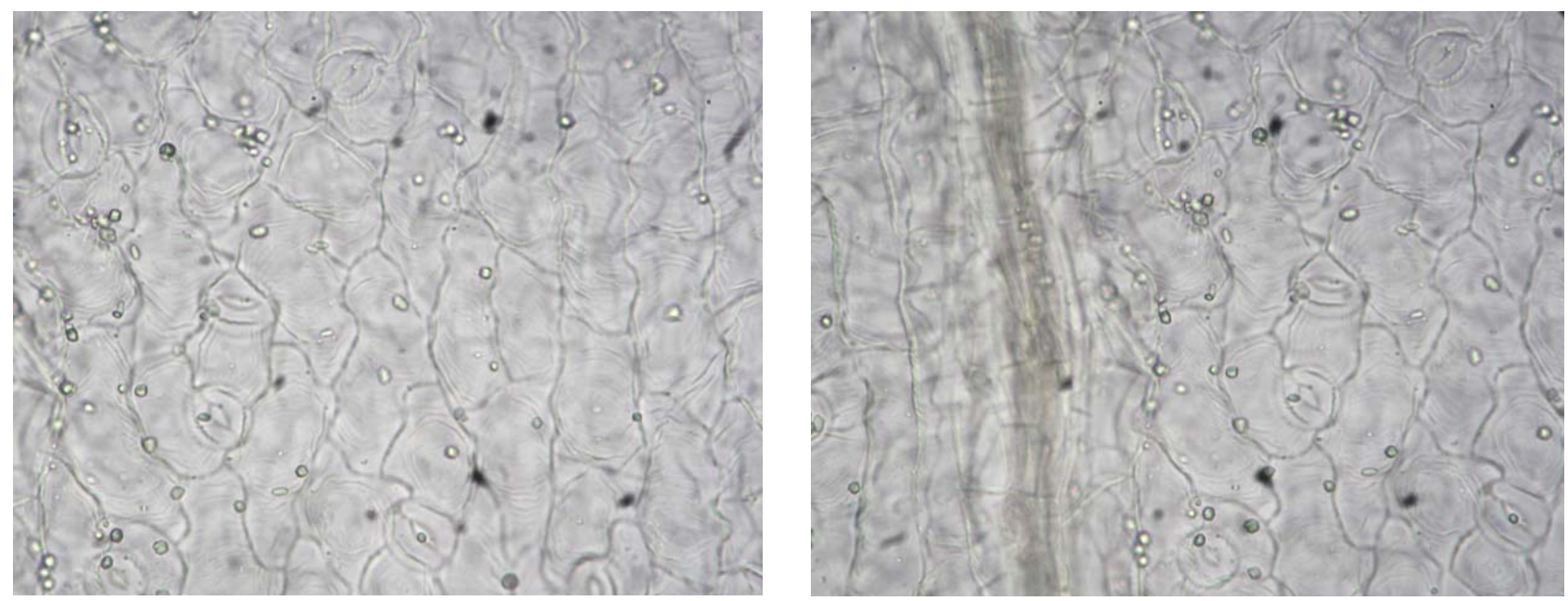

Рис. 3. Нижня епідерма астрагалу солодколистого (зб.1:400).
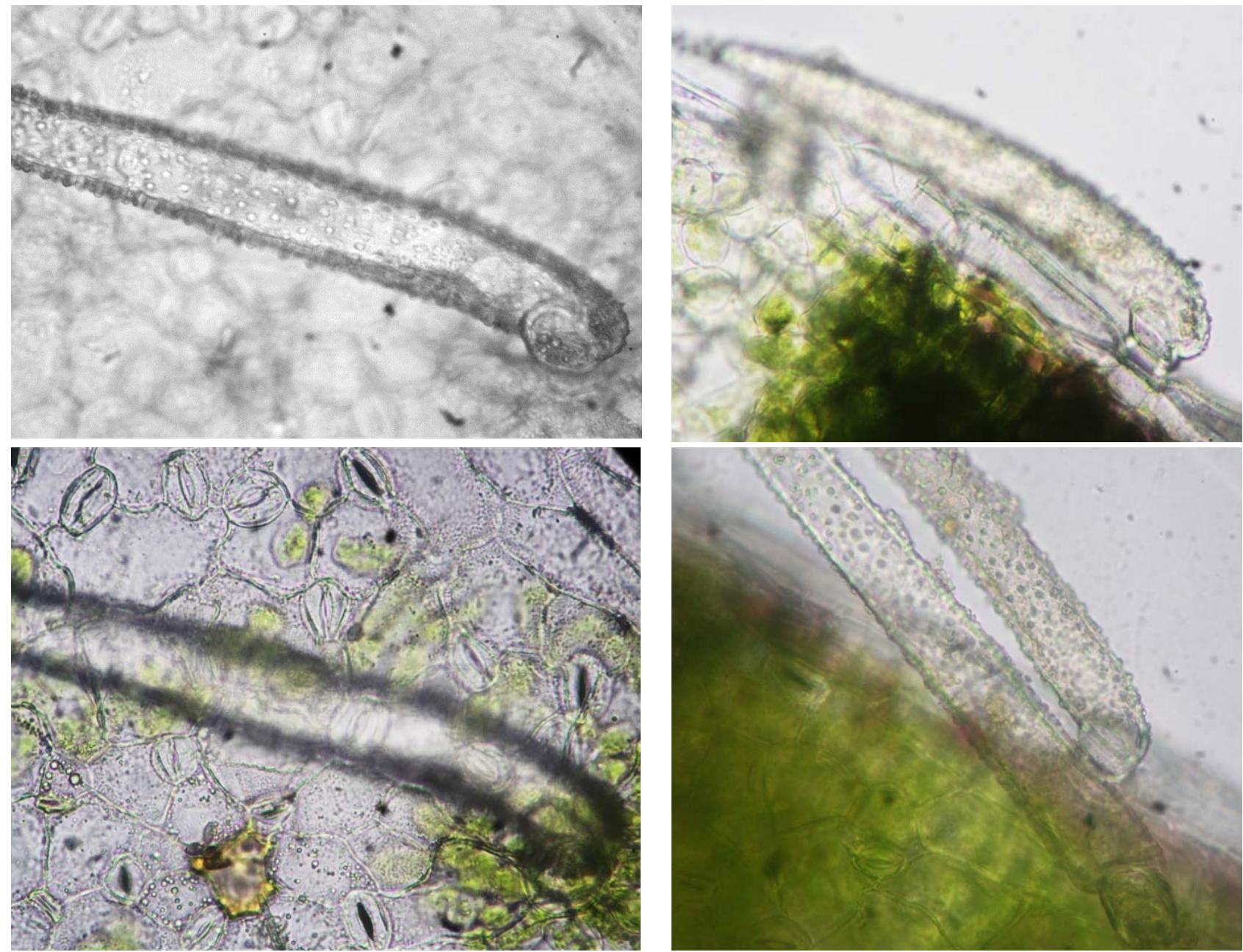

Рис. 4. Притиснутий до епідерми волосок (зб.1:400).

ISSN 2312-0967. Pharmaceutical review. 2019. № 1 
коротких базальних клітин і однієї великої видовженої термінальної клітини 3 бородавчастою кутикулою. Термінальна клітина прикріплюється до ніжки 3 базальних клітини одним зі своїх країв, який $є$ заокруглений. Інший край термінальної клітини загострений. При розгляданні волоска зверху просвітлюється кругле місце прикріплення термінальної клітини до ніжки волоска. Термінальні клітини містять повітря. Епідермальні клітини навколо волоска фрормують нечітку розетку. В мезофрілі зустрічаються дрібні кристали кальцію оксалату овальної фрорми, які розміщені поодиноко або групами.

Епідерма пелюстки (рис. 5) складається $з$ видовжених прямокутних тонкостінних клітин із сильнозвивистими стінками і зморшкуватою кутикулою. На епідермі чашолистка (рис. 6) зустрічаються такі ж самі за будовою прості волоски, як і на листках, тільки тонкостінні. Епідермальні клітини чашолистка округлої форми, тонкостінні, слабозвивисті. Особливо багато їх накопичується по краях зубчиків чашечки. Поміж стромою пиляка (рис. 7) потрапляють в поле зору пилкові зерна округлої фрорми із хвилястою екзиною (рис. 8).

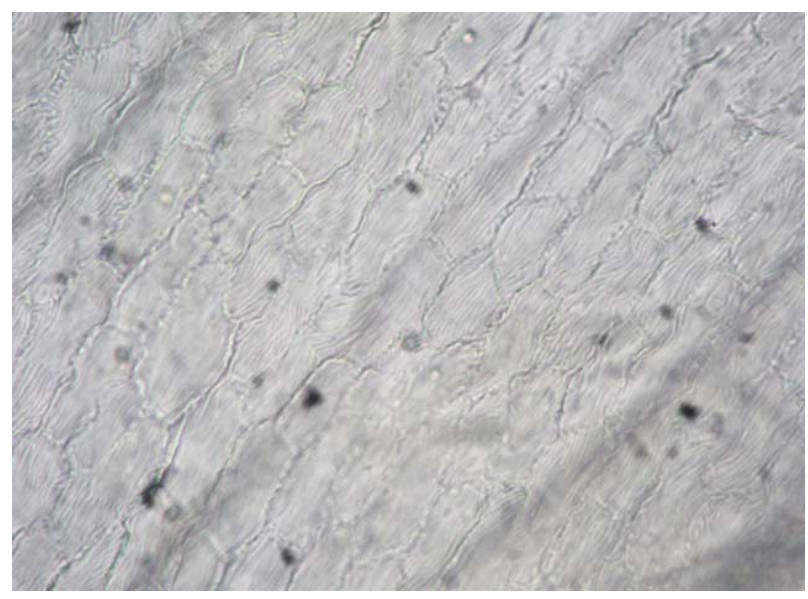

На поперечному перерізі свіжої трави АС через центральну жилку листкової пластинки (рис. 9) спостерігаємо один крупний колатеральний провідний пучок, оточений з усіх сторін механічними волокнами (рис. 10). Тип будови листкової пластинки дорзивентральний, до верхньої епідерми прилягають 2-3 шари стовпчастого мезофрілу, під яким розміщується губчастий мезофріл.

Рахіс листка в поперечному перерізі має серцеподібну будову (рис. 11). Будова пучкова, складається 35 колатеральних провідних пучків, причому 3 з них крупніші від двох інших. Кожен пучок оточений механічними деревними і луб'яними волокнами жовто-коричневого кольору. Епідерма покрита тонким шаром кутикули. Під епідермою розміщується пластинчаста коленхіма, яка складається 3 2-3 рядів клітин. Нижче від коленхіми $€$ шар хлорофрілоносної тканини, яка складається 3 1-2 рядів клітин. Всередині розташовується крупноклітинна запасаюча тканина.

Стебло A. glycyphyllos перехідної будови (рис. 12). Епідерма покрита тонким шаром кутикули. Під епідермою розміщується дворядна пластинчаста коленхіма.

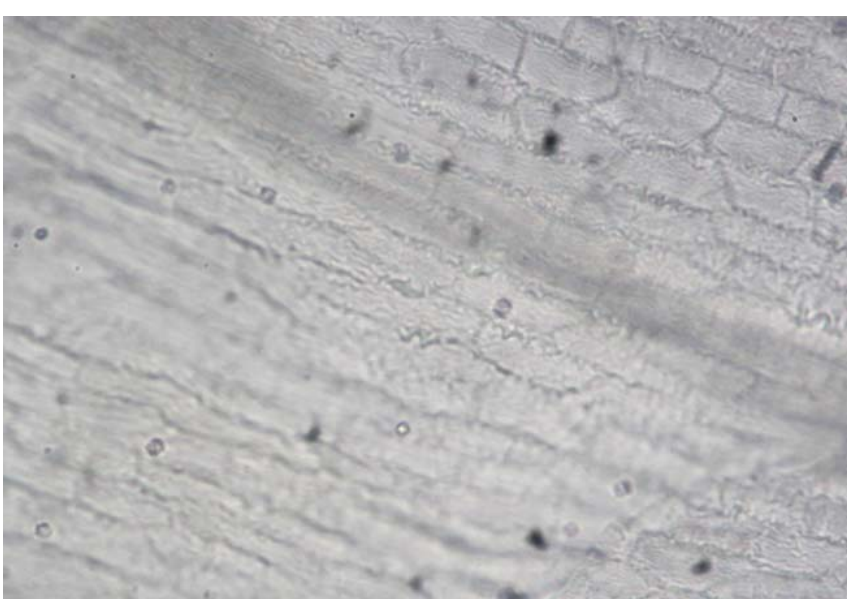

Рис. 5. Епідерма пелюстки (зовнішня і внутрішня), зб.1:100.
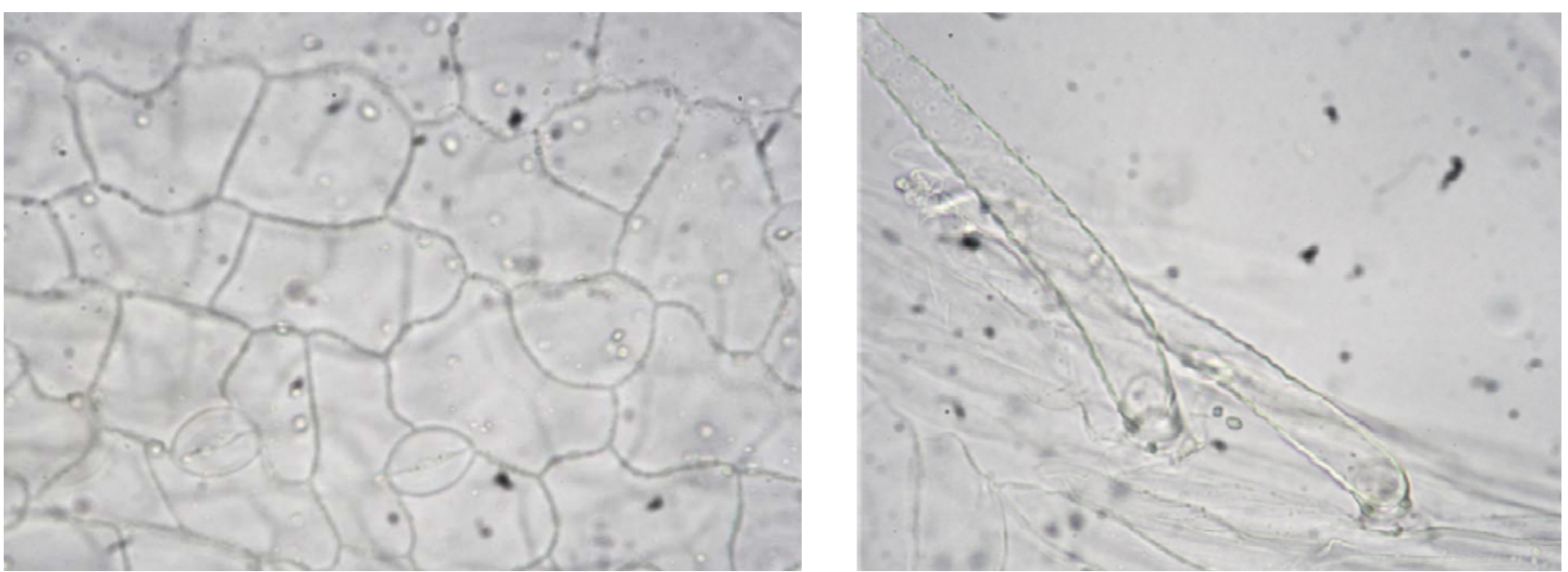

Рис. 6. Епідерма чашолистка, зб.1:100. 
Фітохімічні дослідження

Phytochemical researches

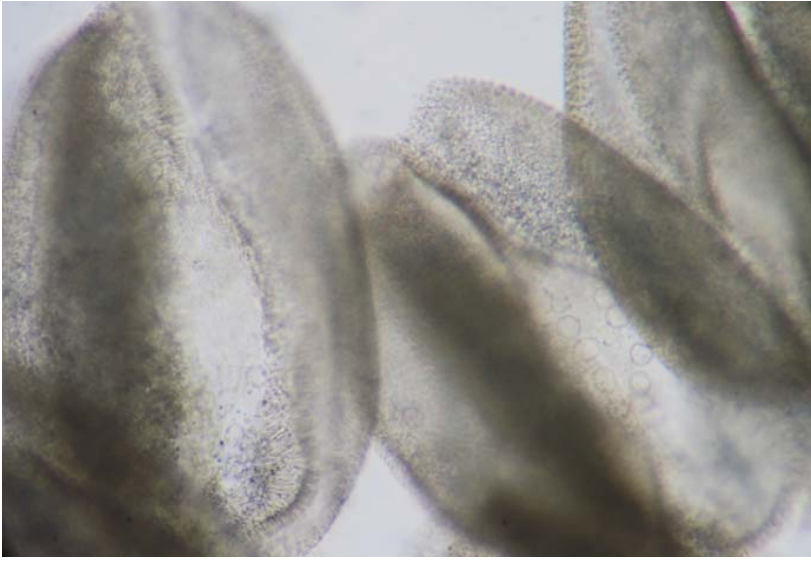

Рис. 7. Пиляки, зб.1:100.

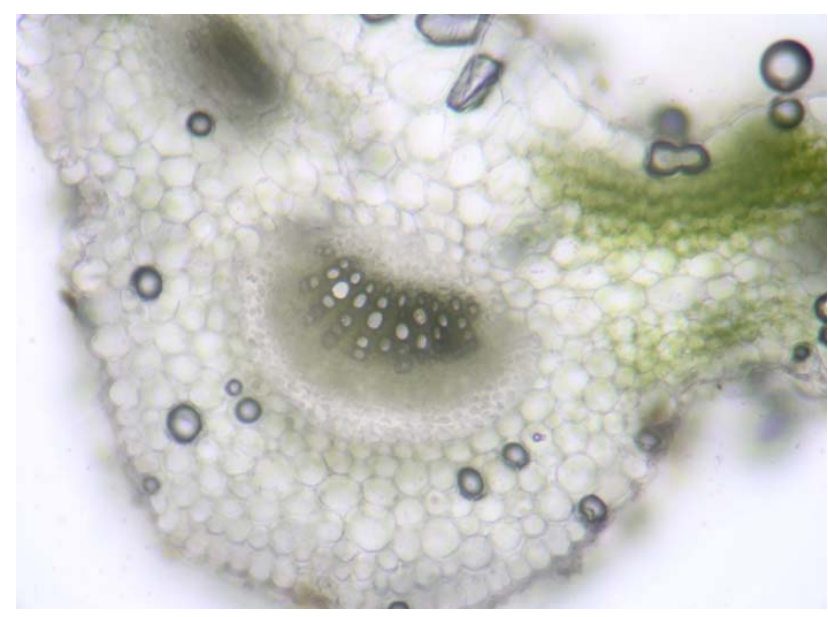

Рис. 9. Поперечний переріз через центральну жилку листкової пластинки, зб. 1:100.

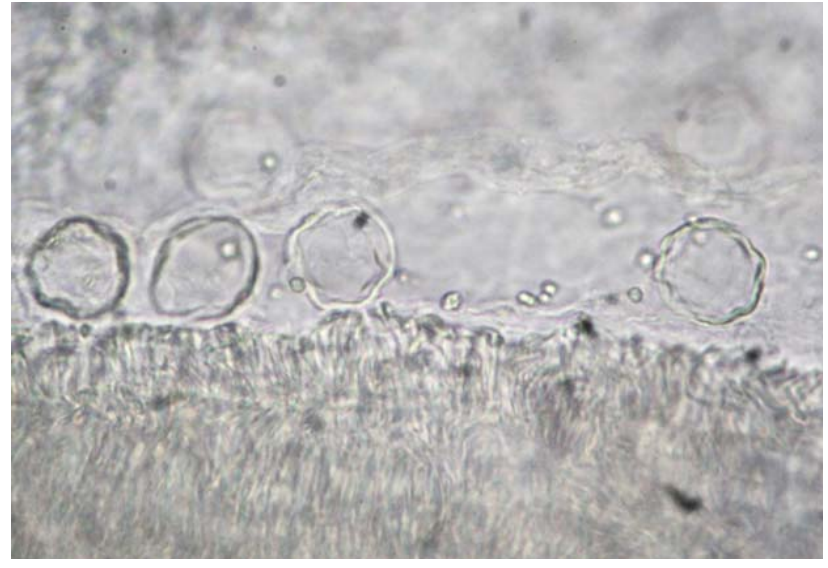

Рис. 8. Пилкові зерна, зб.1:400.

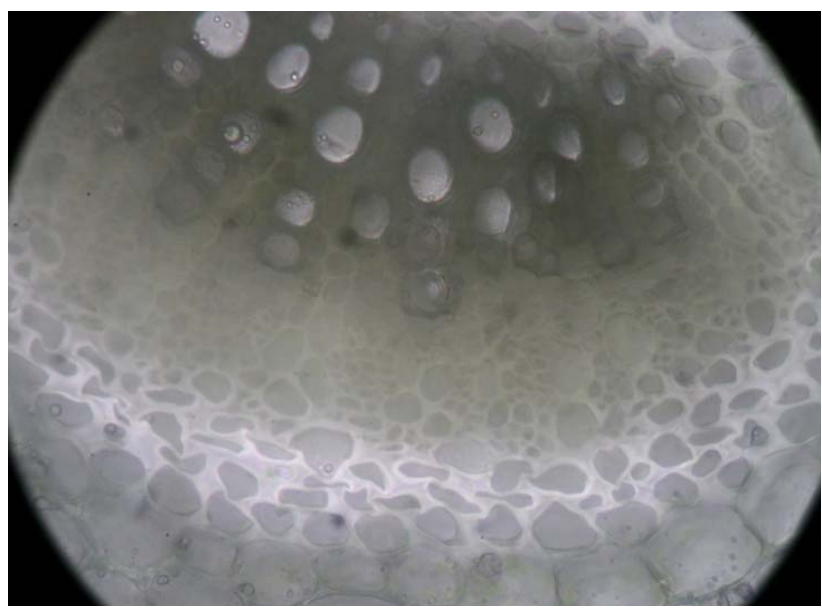

Рис. 10. Відкритий колатеральний провідний пучок центральної жилки листкової пластинки, зб. 1:400.
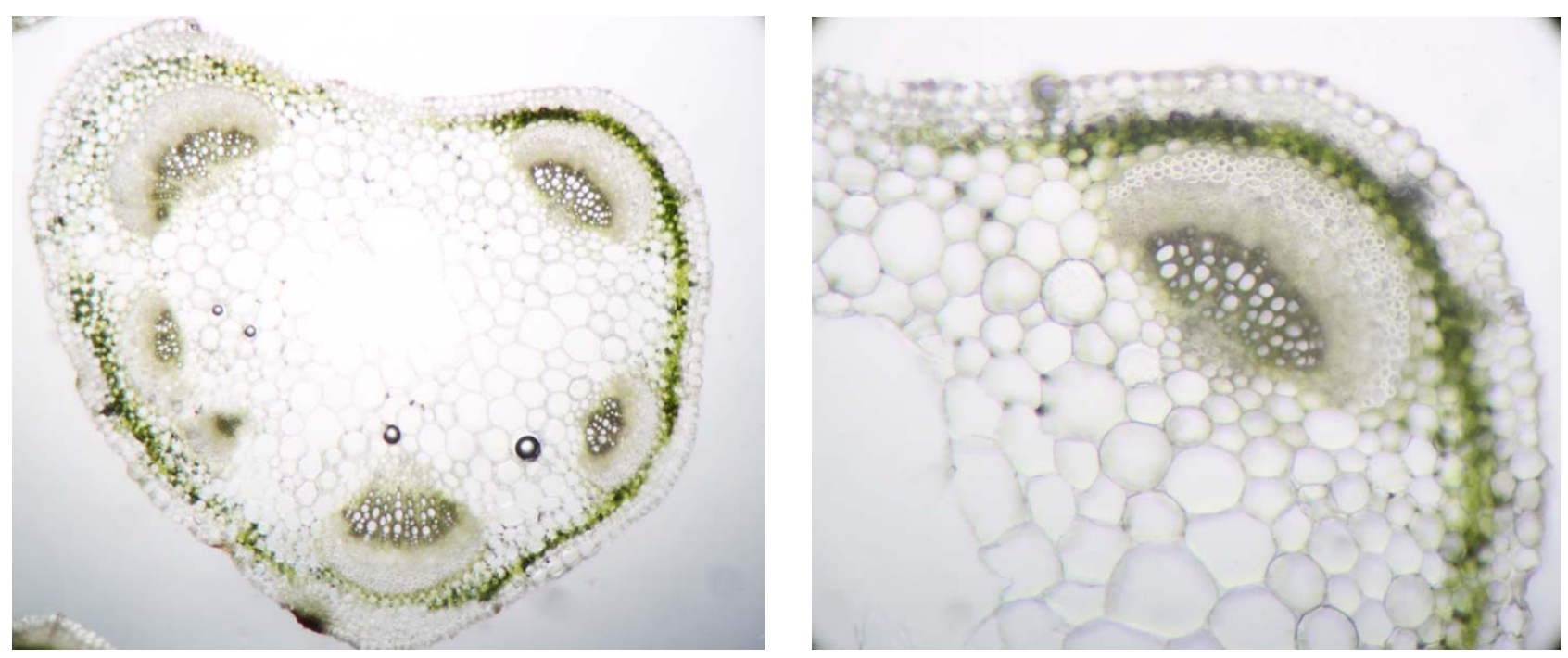

Рис. 11. Поперечний переріз через рахіс, зб. 1:100, зб.1:400.

\section{ISSN 2312-0967. Pharmaceutical review. 2019. № 1}



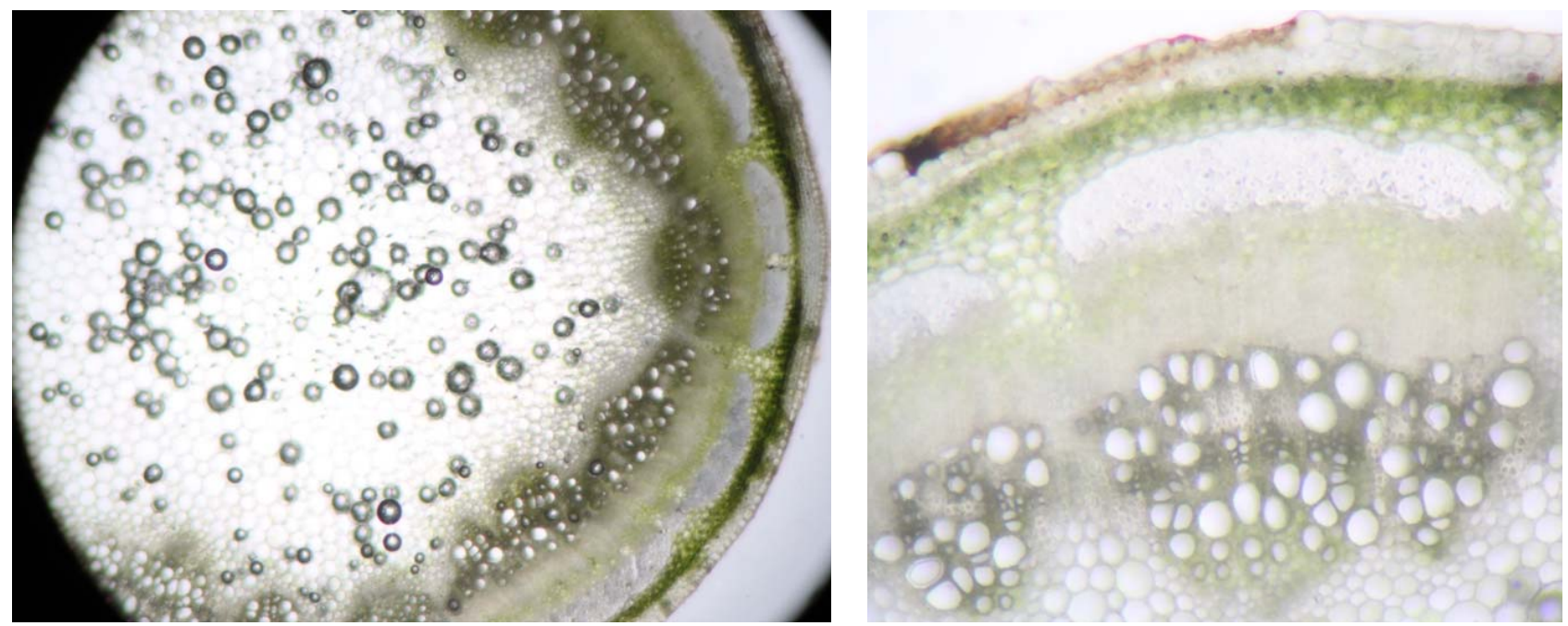

Рис. 12. Поперечний переріз через стебло, зб. 1:40, зб.1:100.

Під коленхімою розміщений шар хлоренхіми, який між зоною луб'яних волокон стиснутий до трикутної форми. Зона луб'яних волокон за будовою нагадує півмісяці. В серцевині стебла міститься крупноклітинна запасаюча паренхіма.

При вивченні локалізації слизу у свіжій сировині AC 3 допомогою спиртового розчину метиленового синього (1:5000), на поперечному перерізі листкової пластинки, рахіса і стебла чітко видно, що слизи накопичуються в клітинах-ідіобластах запасаючої паренхіми (рис. 13). У поодиноких клітинах паренхіми забарвлення слизу з реактивом при проведенні дослідження на свіжій сировині залишається насиченого синього кольору. Пектинові речовини в міжклітинному просторі луб'яних волокон і клітин коленхіми забарвлюються в темно-синій колір.

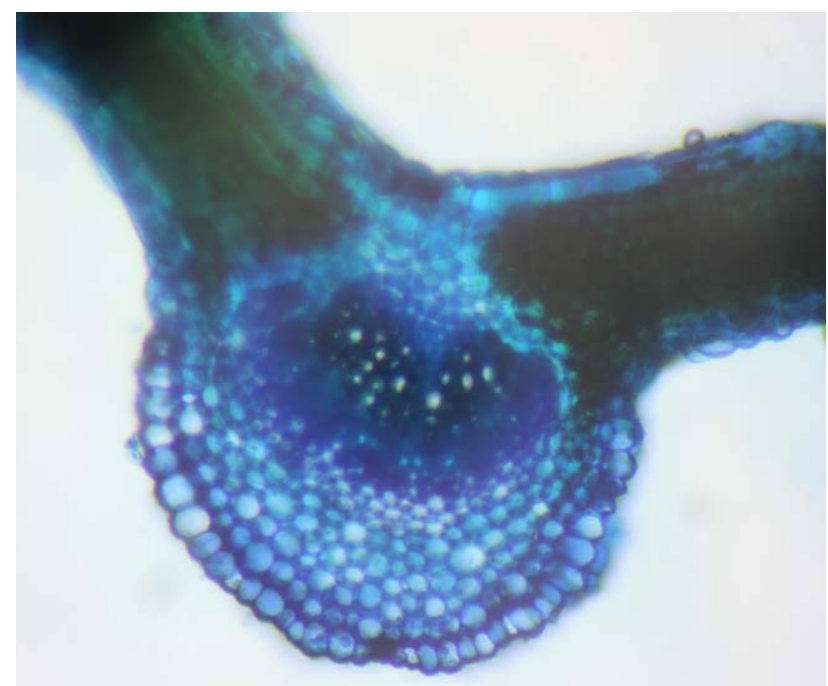

При вивченні локалізації френольних сполук у свіжій сировині з використанням 3 \% розчину фреруму (III) хлориду, на поперечному перерізі листкової пластинки, рахіса і стебла (рис. 14) чітко видно, що френольні сполуки накопичуються в ділянці фрлоеми, хлорофрілоносної паренхіми та коленхіми. Забарвлення фенольних сполук 3 реактивом при проведенні дослідження на свіжій сировині темно-коричневого кольору.

Висновки. Морфолого-анатомічними дослідженнями встановлено видові макро- і мікроскопічні характеристики надземної частини Astragalus glycyphyllos L., які будуть використані при складанні проектів методів контролю якості (МКЯ) на новий вид ЛРС - «Трава астрагалу солодколистого».

Конфлікт інтересів: відсутній.

Conflicts of interest: author has no conflict of interest to declare.

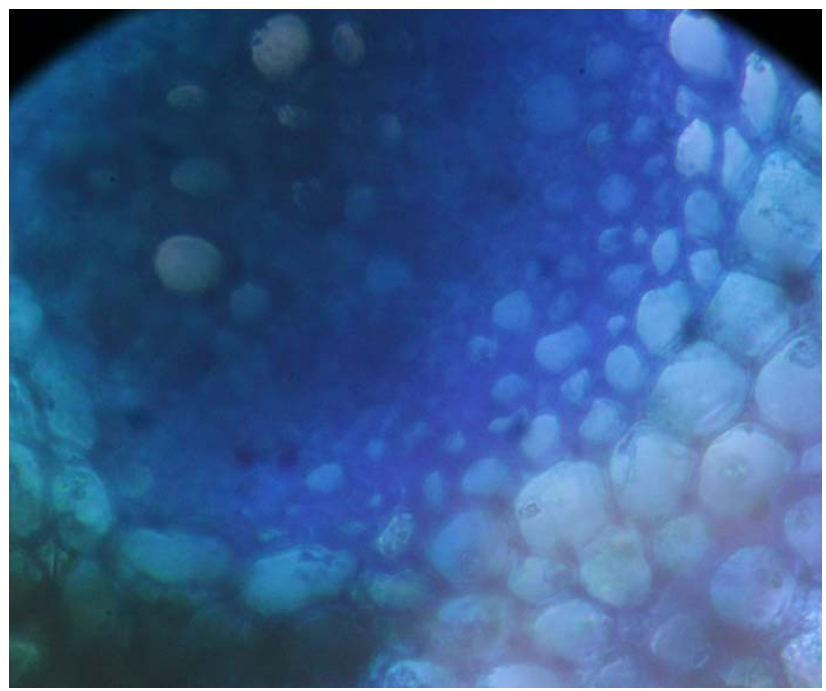

Рис. 13. Локалізація слизу і пектинових речовин у свіжій сировині астрагалу солодколистого, зб. 1:100, зб.1:400.

ISSN 2312-0967. Фармацевтичний часопис. 2019. № 1 

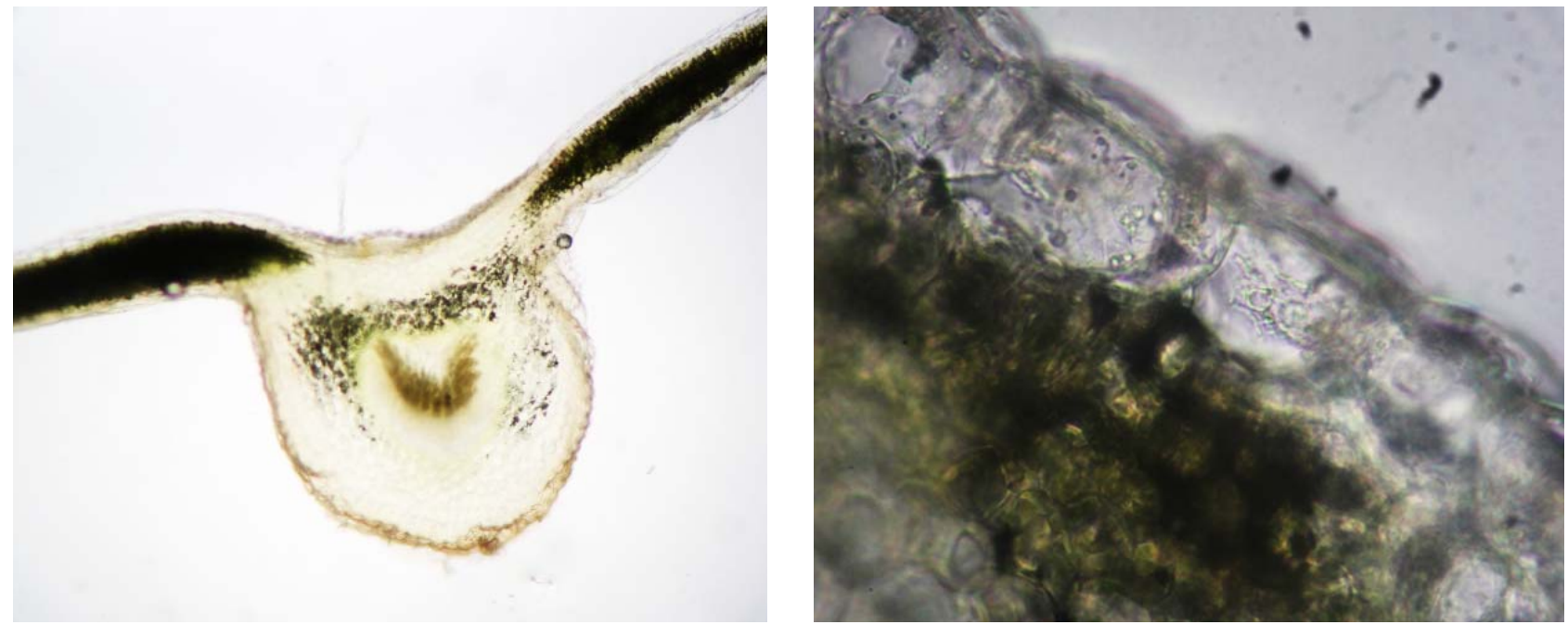

Рис. 14. Локалізація френольних сполук у свіжій сировині астрагалу солодколистого, зб. 1:100, зб.1:400.

\section{МОРФОЛОГО-АНАТОМИЧЕСКОЕ ИССЛЕДОВАНИЕ ТРАВЫ АСТРАГАЛА СЛАДКОЛИСТНОГО (ASTRAGALUS GLYCYPHYLLOS L.)}

\section{Р. Н. Лысюк ${ }^{1}$, Н. П. Ковальская ${ }^{2}$}

Львовский национальный медицинский университет имени Данила Галицкого ${ }^{1}$ Национальный медицинский университет имени А. А. Богомольца², Киев

pharmacognosy.org.ua@ukr.net

Цель работы. Установление морфолого-анатомических диагностических признаков травы астрагала сладколистного.

Материалы и методы. Микропрепараты изготавливали из фррагментов травы астрагала сладколистного фиксированных в растворе хлоралгидрата, и исследовали общепринятыми методами с использованием тринокулярного светового микроскопа ULAB при увеличении в 40, 100 и 400 раз; фротофриксацию результатов осуществляли с помощью зеркальной фотокамеры Canon EOS 550.

Результаты и обсуждение. Диагностическими микроскопическим признаками сырья можно считать трихомы, состоящих из 1-2 коротких базальных клеток и одной большой удлиненной терминальной клетки с бородавчатой кутикулой; терминальная клетка прикрепляется к ножке из базальных клеток одним из своих краев, который является закругленным, другой же ее край есть заостренным. Проведено исследование фррагментов высушенных и свежесобранных листьев, стеблей, рахиса и цветков; в результате проведенного анализа поперечных срезов из свежей травы астрагала сладколистного установлены особенности локализации слизи, пектинов и фенольных соединений в анализируемом растительном сырье.

Выводы. Установлено морсологические и анатомические диагностические признаки надземной части астрагала сладколистного, перспективного нефропротекторного средства. Полученные данные будут использованы при разработке проекта методик контроля качества на новое лекарственное растительное сырье - «Трава астрагала сладколистного».

Ключевые слова: астрагал сладколистный; трава; несропротектор; морфологические, анатомические признаки.

ISSN 2312-0967. Pharmaceutical review. 2019. № 1 
Фітохімічні дослідження

Phytochemical researches

\title{
MORPHOLOGICAL AND ANATOMIC INVESTIGATION OF WILD LICORICE (ASTRAGALUS GLYCYPHYLLOS L.) HERB
}

\author{
R. M. Lysiuk ${ }^{1}$, N. P. Kovalska ${ }^{2}$ \\ Danylo Halytsky Lviv National Medical University ${ }^{1}$, \\ O. Bohomolets National Medical University', Kyiv \\ pharmacognosy.org.ua@ukr.net
}

The aim of the work. Determination of morphological and anatomic diagnostic characters of aerial portion of Astragalus glycyphyllos.

Materials and Methods. The micronutrients were made from the fragments of wild licorice herb, fixed in a solution of chloral hydrate with further investigation by generally accepted methods using a trinocular light microscope ULAB with the following 40X, 100X and 400X magnification settings; photographs of the research results were performed with a mirror photo camera Canon EOS 550.

Results and Discussion. As diagnostic micropreparations features of the raw material can be considered the following: trichomes, which consist of 1-2 short basal cells and one large elongated terminal cell with cuticular wart; the terminal cell is attached to the stalk of the basal cells by one of its margins, which is rounded, the other one is acute. The study of fragments of dried and freshly picked leaves, stems, rachis and flowers was carried out; as a result of the performed analysis of transverse sections from fresh aerial portion of wild licorice, features concerning localization of mucilages, pectins and phenolic compounds in the analyzed plant material were established.

Conclusions. The morphological and anatomical diagnostic features of the above-ground parts of Astragalus glycyphyllos, a promising nephroprotective agent, were established. The received data will be used to develop a draft of quality control methods for a new medicinal plant material - Herba Astragali glycyphylli.

Key words: Astragalus glycyphyllos; wild licorice; herb; nephroprotector; morphological and anatomic characteristics.

\section{Список літератури}

1. Аналіз номенклатури та складу сучасних лікарських засобів рослинного походження для лікування захворювань сечовидільної системи / [Р. М. Лисюк, Р. Є. Дармограй, Н. І. Гудзь та ін.] // Збірник наукових праць співробітників НМАПО імені П. Л. Шупика. Випуск 24. Книга 4. - Київ, 2015. - С. 264-271.

2. Mineral and phytochemical profiles and antioxidant activity of herbal material from two temperate Astragalus Species / B. Butkute, A. Dagilyte, R. Benetis [et al.] // BioMed Research International. - 2018. 11 p. - Article ID 6318630 URL : https://doi.org/10.1155/2018/6318630

3. Белоус В. Н. Виды рода Astagalus L. и их роль в растительном покрове Предкавказья : дисс. ... канд биол. наук : 03.00.05 - ботаника. - Ставрополь, 2005.

4. Ковальова А. М. Флавоноїди рослин роду Astragalus ᄂ. фрлори країн СНД / A. М. Ковальова // Вісник фрармації. - 1998. - № 1. - С. 42-47.

5. Лобанова И. Е. Фитохимическая характеристика Astragalus glycyphyllos (Fabaceae) / И. Е. Лобанова // Растительный мир Азиатской России. - 2011. - № 1. - С. 87-90.

6. Pistelli L. Secondary metabolites of genus Astragalus: Structure and biological activity / L. Pistelli. - In: Atta-UrRahman, editor // Studies in Natural Products Chemistry. Vol. 27. Amsterdam - Boston - London - New York - Oxford - Paris - San Diego - San Francisco - Singapore - Sydney - Tokyo: Elsevier Science B.V. - 2002. - P. 443-545.

7. Растительные ресурсы СССР: цветковые растения, их химический состав, использование: Семейства Нуdrangeaeceae - Haloragaceaе. - Л. : Наука, 1987. - 326 с. 8. Комендар В. І. Лікарські рослини Карпат. Дикорослі та культурні. - 3 вид., доповн. і переробл. / Ред. О. Козоріз. - Ужгород : Мистецька лінія, 2007. - 504 с.

9. Лікарські рослини: енциклопедичний довідник / Відп. ред. А. М. Гродзінський. - К. : Видавництво «Українська Енциклопедія» ім. М.П.Бажана, Український виробничокомерційний центр «Олімп», 1992. - 544 с.

10. Мінарченко В. М. Лікарські судинні рослини України (медичне та ресурсне значення) / В. М. Мінарченко. Київ : Фітосоціоцентр, 2005. - 324 с.

11. Товстуха Є. С. Новітня фрітотерапія: монографрія / $€$. С. Товстуха. - 4-е вид., доп. і переробл. - К. : Укр. акад. оригін. ідей, 2003. - 479 с.

12. Lysiuk R. GLC/MS - Determination of monosaccharides contents in above-ground portions of Astragalus glycyphyllos L. / R. Lysiuk, M. Skibitska, M.-P. Stecko // Медичний фрорум (Medychny forum). - 2015. - Vol. 6 (06). - P. 66-69. 13. Kozhuharov S. ed. Field guide to the vascular plants in Bulgaria. - Sofia: Naouka \& Izkoustvo; 1992.

14. Lysiuk R. Pharmacology and ethnomedicine of the genus Astragalus / R. Lysiuk, R. Darmohray // International Journal of Pharmacology, Phytochemistry and Ethnomedicine. - 2016. - Vol. 3. - P. 46-53. doi:10.18052/www.scipress.com/IJPPE.3.46

15. Карпусь І. П. Морфолого-анатомічне дослідження астрагалу шерстистоквіткового (Astragalus dasyanthus Pall) родини Бобових (Leguminosae) / І.П. Карпусь // Фармацевтичний журнал. - 1961. - № 12. - С. 33-37.

16. Сіра Л. М. Макро- і мікроскопічне дослідження Astragalus falcatus Lam. / Л. М. Сіра, Г. В. Куцик, Т. П. Куцик // Вiсн. фрармації. - 2005. - № 2. - С. 21-25.

ISSN 2312-0967. Фармацевтичний часопис. 2019. № 1 
17. Особенности фрармацевтической разработки лекарственных средств на основе растительных субстанций / [Езерская О. И., Р. Н. Лисюк, Н.И.Гудзь и др.] // Разработка, исследование и маркетинг новой фрармацевтической продукции : сборник научных трудов. - Пятигорск : Пятигорский медико-срармацевтический институт-филиал ГБОУ ВПО ВолгГМУ Минздрава России, 2015. - Вып. 70. - С. 109-112.

\section{References}

1. Lysiuk RM, Darmohray RY, Gudz NI, et al. [Analysis of nomenclature and composition of current herbal drugs for treatment of urinary system disorders]. Zbirnyk naukovykh prats spivrobitnykiv NMAPO imeni P.L.Shupyka. Kyiv. 2015;24(4): 264-271. Ukrainian.

2. Butkut B, Dagilyt A, Benetis R, Padarauskas A, Cesevilien $\mathrm{J}$, Olšauskait $\mathrm{V}$, et al. Mineral and phytochemical profiles and antioxidant activity of herbal material from two temperate Astragalus species. BioMed Research International. 2018;11. Article ID 6318630. Available at: https://doi. org/10.1155/2018/6318630

3. Belous VN. [Species of the genus Astagalus L. and their role in the vegetation cover of Precaucasia]. Dissertation. PhD (Biol.), 03.00.05 - Botany. Stavropol; 2005. Russian.

4. Kovalova AM. [Flavonoids of plants of the genus Astragalus L. in flora of the CIS countries]. Visnyk farmatsii. 1998;1: 42-7. Ukrainian.

5. Lobanova IE. [Phytochemical characteristics of Astragalus glycyphyllos (Fabaceae)]. Rastitelnyy mir Aziatskoy Rossii. 2011;1: 87-90. Russian.

6. Pistelli L. Secondary metabolites of genus Astragalus: Structure and biological activity. In: Atta-Ur-Rahman, editor. Studies in Natural Products Chemistry, Vol. 27. Amsterdam - Boston - London - New York - Oxford - Paris - San Diego - San Francisco - Singapore - Sydney - Tokyo: Elsevier Science B.V.; 2002.

7. [Plant resources of the USSR: Flowering plants, their chemical composition, use: Family Hydrangeaeceae Haloragaceae.]. Leningrad: Nauka; 1987. Russian.

8. Komendar VI. [Medicinal plants of the Carpathians. Wild and Cultural. $3^{\text {rd }}$ ed]. Editor O. Kozoriz. Uzhhorod: Mystetska liniia; 2007. Ukrainian.

9. [Medicinal plants: Encyclopaedic handbook]. Editor Grodzinsky AM. "Ukrainska Entsyklopediia" im. M.P. Bazhana, Ukrain-
18. Flora Europaea. Vol. 2. Rosaceae to Umbelliferae / T. G. Tutin, V. H. Heywood, N. A. Burges [et al.]. - London - New York - New Rochelle - Melbourne - Sydney: Cambridge University Press; 1981.

19. Определитель высших растений Украины / [Д. Н. Доброчаева, М. Т. Котов, Ю. Н. Прокудин и др.] Киев : Наук. думка, 1987. - 548 с.

skyi vyrobnycho-komertsiinyi tsentr "Olimp"; 1992. Ukrainian. 10. Minarchenko VM. [Medicinal vascular plants of Ukraine (medical and resource value)]. Kyiv: Fitosotsiotsentr; 2005. Ukrainian. 11. Tovstukha YeS. [Current phytotherapy: monograph. 4th ed.]. Kyiv: Ukr. akad. oryhin. Idei; 2003. Ukrainian.

12. Lysiuk R, Skibitska M, Stecko M.-P. GLC/MS - Determination of monosaccharides contents in above-ground portions of Astragalus glycyphyllos L. Медичний фрорум (Medychny forum). 2015;6(06): 66-9.

13. Kozhuharov S. editor. Field guide to the vascular plants in Bulgaria. Sofia: Naouka \& Izkoustvo; 1992.

14. Lysiuk R, Darmohray R. Pharmacology and ethnomedicine of the genus Astragalus. International Journal of Pharmacology, Phytochemistry and Ethnomedicine. 2016;3:4653. doi:10.18052/www.scipress.com/IJPPE.3.46

15. Karpus IP. [Morphological and anatomical study of Astragalus dasyanthus Pall, Leguminosae]. Farmatsevtychnyi zhurnal. 1961;12: 33-7. Ukrainian.

16. Sira LM, Kutsyk HV, Kutsyk TP. [Macro- and microscopic study of Astragalus falcatus Lam.]. Visnyk farmatsii. 2005;2: 21-5. Ukrainian.

17. Yezerska OI, Lysiuk RM, Gudz NI, et al. [Features of the pharmaceutical development of herbal medicinal products]. Razrabotka, issledovaniye i marketing novoy farmatsevticheskoy produktsii: sbornik nauchnykh trudov. Pyatigorsk: Pyatigorskiy mediko-farmatsevticheskiy institut-filial GBOU VPO VolgGMU Minzdrava Rossii. 2015;70: 109-12. Russian.

18. Tutin TG, Heywood VH, Burges NA, Moore DM, Valentine $\mathrm{DH}$, Walters SM, et al. (Eds). Flora Europaea. Vol.2. Rosaceae to Umbelliferae. London - New York - New Rochelle - Melbourne - Sydney: Cambridge University Press; 1981.

19. Dobrochaeva DN, Kotov MT, Prokudin YN, et al. [The determinant of higher plants of Ukraine]. Kyiv: Naukova dumka; 1987. Russian.

Надійшла до редакції / Received: 25.02.2019 Після доопрацювання / Revised: 15.03.2019 Прийнято до друку / Accepted: 22.03.2019

\section{Відомості про авторів:}

Лисюк Р.М. - асистент кафр. фрармакогнозії і ботаніки, Львівський національний медичний університет імені Данила Галицького, Львів, Україна. E-mail: pharmacognosy.org.ua@ukr.net, ORCID 0000-0003-0961-2970

Ковальська Н.П. - канд. фрармац. н., доц. кафр. фрармакогнозії та ботаніки, Національний медичний університет імені О.О. Богомольця, Київ, Україна. E-mail: tsveyuk@gmail.com, ORCID 0000-0003-2673-5446

\section{Information about authors:}

Lysiuk R. M. - assistant of the Pharmacognosy and Botany Department, Danylo Halytsky Lviv National Medical University, Lviv, Ukraine. E-mail: pharmacognosy.org.ua@ukr.net, ORCID 0000-0003-0961-2970

Kovalska N.P. - PhD (Pharmaceutical Sciences), Associate Professor of the Pharmacognosy and Botany Department, O.O. Bohomolets National Medical University, Kyiv, Ukraine. E-mail: tsveyuk@gmail.com, ORCID 0000-0003-2673-5446

ISSN 2312-0967. Pharmaceutical review. 2019. № 1 